УДК 342.1 : 342.7-049.65

\title{
ПРАВОВА ДЕРЖАВА ЯК НЕВІД'ЄМНА СКЛАДОВА ЗАХИСТУ ПРАВ ЛЮДИНИ
}

\section{Биркович Тетяна Іванівна}

доктор з державного управління, професор,

Київський університет культури,

м. Київ, Украӥна

ORCID: 0000-0003-3276-2029

byrkovychtetiana@gmail.com
Надіслано:

13.03.2019

Рецензовано:

25.03.2019

Прийнято:

16.04.2019

\section{Кабанець Олександр Сергійович}

кандидат юридичних наук, доцент,

Київський університет культури

м. Київ, Україна

ORCID: 0000-0003-1272-6725

kabanets.flo@gmail.com

У статті розглядається захист прав людини в правовій та демократичній державі. У контексті захисту прав людини досліджується концепція правової держави та принцип верховенства права, який спирається на розмежування права i закону. Також досліджується, що держава практично набуває характеристики соціальної злагоди, коли має на меті реалізацію прав людини на гідне життя, покладає на себе обов'язки щодо виконання значної за обсягом соціальної функції - проведення соціальної політики, спрямованої на розробку і здійснення системи реформ, заходів соціального захисту населення. Реальність свідчить про те, що людина виявляється менш захищеною перед державою і механізм ії відповідальності є досить ефективним, на відміну від механізму відповідальності держави перед особою, який в Україні практично не діє. А саме останнє в контексті розвитку правової держави є свідченням певного рівня демократичних перетворень. Тому особливу увагу в контексті становлення правової держави потрібно приділяти інституту відповідальності держави перед особою, як одній з основних гарантій прав і свобод людини, закріплених у чинному законодавстві. Завдяки цьому досягається послаблення тиску держави на суспільство і водночас підвищується можливість його контролю за діями держави, за рішеннями її органів та посадових осіб.

Ключові слова: держава; демократія; правова держава; демократична держава; законність; людина; захист прав людини. 
Byrkovych Tetiana, Doctor of Public Administration, Professor, Kyiv University of Culture, Kyiv, Ukraine;

Kabanets Oleksandr, Ph.D. in Law, Associate Professor, Kyiv University of Culture, Kyiv, Ukraine

\section{Legal state as an integral part of human rights protection}

The article discusses the protection of human rights in a legal and democratic country. In the context of the human rights protection, the concept of the rule of law and the principle of the rule of law, based on the distinction between law and principle, is explored. It also examines that the state practically acquires the characteristics of social harmony when it has the goal of realizing the human right to a decent life, imposes obligations to perform a significant social function the implementation of social policies aimed at developing and implementing a system of reforms and social protection measures. The reality indicates that a person is less protected before the state and the mechanism of its responsibility is quite effective, unlike the mechanism of responsibility before the person, in Ukraine it practically does not work. And the latest in the context of the development of a legal state is evidence of a certain level of democratic transformations. Therefore, special attention in the context of the formation of a legal state should be paid to the institution of responsibility before a person, as one of the basic guarantees of human rights and freedoms enshrined in current legislation. Thanks to this, a weakening of the state's pressure on society is achieved, and at the same time the possibility of its control over the actions of the state and the decisions of its organs and officials is increased.

Key words: state; democracy; rule of law; democratic state; legality; person; protection of human rights.

Биркович Татьяна Ивановна, доктор государственного управления, профессор, Киевский университет культуры, Киев, Украина;

Кабанец Александр Сергеевич, кандидат юридических наук, доцент, Киевский университет культуры, г. Киев, Украина

Правовое государство как неотъемлемая составляющая защиты прав человека

В статье рассматривается защита прав человека в правовой и демократической стране. В контексте защиты прав человека исследуется концепция правового государства и принцип верховенства права, который опирается на разграничение права и закона. Также проводятся исследование того, что государство практически приобретает характеристики социального согласия, целью которого является реализация прав человека на достойную жизнь; государство возлагает на себя обязанности по выполнению значительной по объему социальной функции - реализации социальной политики, направленной на разработку и осуществление системы реформ, мер 
социальной защиты населения. Реальность свидетельствует о том, что человек оказывается менее защищенным перед государством и механизм его ответственности является достаточно эффективным, в отличие от механизма ответственности перед лицом, в Украине практически не действует. Это в контексте развития правового государства является свидетельством определенного уровня демократических преобразований. Поэтому особое внимание в контексте становления правового государства нужно уделять институту ответственности перед лицом, как одной из основных гарантий прав и свобод человека, закрепленных в действующем законодательстве. Благодаря этому достигается ослабление давления государства на общество и одновременно повышается возможность его контроля за действиями государства, по решениям ее органов и должностных лиц.

Ключевые слова: государство; демократия; правовое государство; демократическое государство; законность; человек; защита прав человека.

\section{Вступ}

Починаючи від джерел свого виникнення, поняття демократичної держави було тісно пов'язане з різноманітними практиками безпосереднього народного волевиявлення, коли громадяни античних полісів отримували змогу не лише висловлювати свою думку щодо тих чи інших питань публічного життя, а й безпосередньо впливати на дії держави та органи державної влади (Tolstenko, 2014, p. 172).

\section{Аналіз останніх досліджень та публікацій}

Останнім часом зазначену проблематику досліджували П. Гончаров, О. Дзьобань, О. Зайчук, М. Козюбра, I. Кресіна, В. Культенко, . Лаба, М. Марченко, А. Матвієнко, Н. Оніщенко, М. Оніщу, В. Осетинський, Н. Пархоменко, О. Петришин, Б. Попов, П. Рабінович, В. Савельєв, А. Селіванов, О. Скакун, О. Скрипнюк, В. Толстенко, В. Шаповал, Ю. Шемшученко. тощо.

Відповідні зміни в правовій системі демократичного суспільства полягають у тому, що право: пов'язує та обмежує державну владу (правова держава); дедалі більше набуває підстав у природному праві, в невід'ємних правах і свободах людини;набуває удосконаленого, «відпрацьованого» узаконах та інших нормативно-правових актах змісту;стає неподільним, єдиним, незалежним і сильним правосуддям (Kresina, 2016, p. 57).

Постановка завдання, виділення невирішених раніше частин загальної проблеми

Концепція правової держави, власне як і принцип верховенства права, спирається на розмежування права i закону. Право істинне не тому, що записане у законі та існує в офіційній формі, а завдяки своєму змістові. Право має розглядатися у нерозривному зв'язку з правами людини, які $є$ 
безпосередньо діючим правом і можуть застосовуватися всупереч закону, якщо закон суперечить фундаментальним правам людини: не відображає природно-правові начала; не відповідає загальновизнаним міжнародноправовим принципам і нормам про права людини і громадянина; прийнятий нелегітимним органом державної влади тощо (Koziubra, 2003, p. 92).

\section{Формулювання цілі статті}

Отже, у правовій державі має панувати право, а не інтереси осіб, у руках яких перебуває влада, що є виразом утвердження принципу верховенства права у державі.

\section{Виклад основного матеріалу дослідження}

Для правової держави, як зазначає В. Савельєв, необхідно, щоб усі, зокрема й сама держава, дотримувалися законів з тією лише умовою, щоб самі ці закони були правовими (Saveliev, 1997, p. 45).

Які ж критерії «правових законів»? Які закони можна розглядати як такі, що збігаються з правом, а які не можна? Нарешті, які існують об'єктивні підстави для розподілу одних законів до правових, а інших - до неправових? Що саме робить одні закони правовими, а інші - неправовими? Ці та інші подібні питання здавна привертали увагу науковців. Однак остаточної відповіді на них досі не було знайдено. Вчені-юристи та філософи пропонували різні критерії для розмежування права й закону, правових законів і неправових, але всі вони породжували ще більше питань і дискусій (Marchenko, 2007, p. 19-23).

П. Рабінович наголошує, що держава практично набуває характеристики соціальної злагоди, коли має на меті реалізацію прав людини на гідне життя, покладає на себе обов'язки щодо виконання значної за обсягом соціальної функції - «проведення соціальної політики, спрямованої на розробку іздійснення системи реформ і заходів соціального захисту населення» (Rabinovych, 1996, p. 374).

Варто зауважити, що правова система України згідно з Конституцією повинна відповідати демократичному, правовому та соціальному розвиткові держави. Існує органічна єдність демократичної, соціальної, правової держави. Як демократична - вона слугує свободі як вищій цінності, сприяє рівному доступу кожного до власності, виборів, прав щодо здійснення політичної влади, забезпечення багатоманітності політичного і культурного життя. Як правова вона забезпечує організацію соціального і державного життя на принципах права, гарантує правопорядок, сприяє досягненню особистістю самостійності і відповідальності за свої дії, раціональної обгрунтованості юридичних рішень, стабільності правової системи (Shemshuchenko, 2013, р. 8).

Як соціальна - визнає людину найвищою соціальною цінністю, гарантує ïi гідність, надає соціальну допомогу індивідам, що ії потребують, з метою забезпечення кожному гідного рівня життя, розподіляє економічні блага 
відповідно до принципу соціальної справедливості й своє призначення вбачає узабезпеченні громадянського миру і злагоди у суспільстві (Shemshuchenko, 2012, p. 124).

Отже, сучасне розуміння права передбачає визнання людини найвищою соціальною цінністю, а забезпечення та реалізацію невід'ємних прав і свобод людини та громадянина - головною метою діяльності державної влади, яка реалізує свої завдання лише в межах Конституції України (Plavych, 2012, p. 7).

Як справедливо наголошується у юридичній літературі, «права людини - це мінімум загальносоціальних, загальнолюдських та загальнодемократичних вимог до правового та соціального становища кожної особи, реалізація яких повинна й може бути забезпечена в будь-якому суспільстві, незалежно від особливостей його соціально-правової системи» (Marchenko, 1993, p. 173).

Отже, характерною ознакою правової держави є гарантії прав і свобод людини - визнання природних, невід'ємних і невідчужуваних прав і свобод людини вищою соціальною цінністю і безпосередньо чинним правом; гарантування їх здійснення - створення ефективних процедурно-юридичних механізмів їх забезпечення (реалізації, охорони, захисту). Реалізація гарантій цих прав і свобод в ідеалі забезпечується у процесі невтручання держави в справи громадянського суспільства (Selivanov, 2011, p. 19).

Категорія прав людини діє винятково у відносинах між людиною і владою. Права людини - це межі влади. Як справедливо наголошує В. Осетинський, вони визначають ту сферу життєдіяльності людини, в яку влада (держава) не може втручатися і ті обов'язки, які має держава щодо людини. Відносини між людиною і владою передбачають особливий характер: «...Концепція прав людини грунтується на трьох положеннях: по-перше, кожна влада обмежена; по-друге, кожна людина має свій автономний світ, втручатися в який не може жодна сила; по-третє, кожна людина, захищаючи свої права, може висунути претензії до держави» (Osetynskyi, 2019).

О.Зайчук звертає увагу на те, що більшість українських громадян не задоволені тим, як держава та влада забезпечують реалізацію їх законних прав та інтересів. Тому можна говорити про низьку спроможність влади забезпечувати погодженість і реалізацію інтересів соціальних груп і громадян, що створює потенційну основу для можливих політичних конфліктів. Сприйняття державної влади населенням перебувають на незадовільному рівні. Більшість громадян сприймають владу в Україні як таку, що захищає інтереси переважно багатих людей i вищої бюрократії. Це зумовлено неспроможністю держави забезпечити їх відповідними фінансовими ресурсами з огляду на стан вітчизняної економіки (Zaichuk, 2012, p. 26). 
Як наголошує В.Культенко, реальний стан української державності можна охарактеризувати як авторитарний. У ньому присутні елементи демократизму, як то: автономія особи й суспільства від влади в неполітичних сферах, існує недержавний сектор економіки, формальний розподіл гілок влади, багатопартійність і система виборів. Однак домінування виконавчої влади, зрощення державного апарату з апаратом правлячої партії, переважання силових методів управління, відсутність реальної сили громадських організацій в значно гірший бік відрізняють українську державу від правових демократичних держав. Країна перебуває у хиткому стані, коли можливий її перехід як до демократії, так і до тоталітаризму (Kultenko, 2004, p. 10).

Правову державу, яка проводить активну соціальну політику, спрямовану на забезпечення прав і свобод людини, досягнення високого рівня добробуту усіх верств населення, називають ще й соціальною державою (Shliakhtun, 2002, p. 315).

В. Шаповал пов'язує визначення соціальної держави 3 соціальною справедливістю та соціальним захистом. Він вважає, що соціальна держава «це характеристика сучасної держави, за смислом якої державна діяльність має бути спрямована на створення реальних стандартів матеріального добробуту, освіти, охорони здоров'я тощо і забезпечення таких стандартів для усіх громадян (індивідів), а також на мінімізацію фактичної соціальної нерівності 3 iї економічними наслідками та створення системи соціальної підтримки (захисту) тих, хто цього потребує» (Shapova, 2004, p. 14).

Формування сучасних моделей соціальної держави в промислово розвинених країнах відбувалося від початку 60-х рр. ХХ ст. На думку В. Солових, це пов'язано з високою динамікою перетворень економічного та суспільного устрою, які відбувалися під впливом науково-технічної революції та зміни змісту праці. Знання і професійна кваліфікація працівника перетворилися на найбільш важливий чинник виробництва, що виразилося у низці теорій: людського капіталу, якості життя й якості трудового життя (Solovykh, 2009, p. 71).

Еволюціонуючи модель держави з розвиненою системою соціального захисту населення перетворюється на модель держави високої якості життя населення, що знайшло своє відображення в конституціях низки країн. Зокрема, ст. 1 Конституції Іспанії зазначає, що Іспанія є соціальною, правовою та демократичною державою, вищими цінностями якої $\epsilon$ свобода, справедливість, рівність і політичний плюралізм. У Конституції Франції записано, що вона є демократичною і соціальною республікою. При цьому категорії «соціальна держава» або «держава загального добробуту» трактуються західними вченими з позиції виконання державою комплексу соціально-захисних функцій, відповідальності уряду за забезпечення основних 
соціальних потреб громадян, включаючи створення умов для розвитку громадянського суспільства (Goncharov, 2000, p. 50-51).

Також специфічною ознакою такої держави як вищої форми політичного буття є відповідність закону права (правовий закон) і його верховенство, тобто право як міра свободи і справедливості набуває відпрацьованого у законі змісту (Onishchenko, 2007, p. 94).

Як зазначає Б. Попов: «Національне відродження України пов'язане як з реалізацією національної ідеї», так і 3 втіленням у соціальне, політичне і культурне буття українського народу принципів соціальної, правової та демократичної держави (Popov, 1995, p. 237-240).

На переконання К.Ясперса: «Свобода людини починається 3 того моменту, коли в державі, в якій вона проживає, набирають чинності ухвалені закони. Така свобода називається політичною свободою, а держава, в якій діє свобода, що заснована на законах, називається правовою державою» (Jaspers, 1994, p. 214). 3 огляду на цю позицію вбачається, що правовим механізмом функціонування демократії $\epsilon$ правова держава, принципи якої реально реалізуються у житті суспільства.

Тому не випадково класична філософсько-правова думка пов'язує ідею правової держави з ідеєю свободи, автономії особистості. Вона виходить із можливості встановлення таких відносин між людиною й державою, за яких: по-перше, джерелом права вважається особистість, а не держава; по-друге, змінюється уявлення про співвідношення між державою і законом, від звичної формули «закон є інструментом державної влади» здійснюється перехід до принципу «держава є інструментом закону»; по-третє, визнається, що держава стає правовою в силу того, що не суперечить і не порушує права людини, а зміцнює і захищає їх (Dzoban, 2005, p. 24).

Серед науковців, особливо в останні роки, активізувалися дискусї про правову державу як про поняття, що оптимально відображає діалектичний взаємозв'язок держави і права та можливість найбільш ефективного впливу такого зв'язку на сучасний суспільний розвиток. В. Юзвіков зазначає, що у суспільній свідомості все більше стверджується думка про те, що заснована на демократичних принципах правова держава може стати ефективним знаряддям врегулювання конфліктів, які виникають у суспільстві, ствердження у ньому законності і правопорядку» (Yuzvikov, 2004, p. 32). Ці явища безпосередньо пов'язуються з ознаками правової держави, серед яких, як зазначалося вище, принцип верховенства права.

У статті 8 Конституції України вказується, що в Україні визнається і діє принцип верховенства права, що забезпечується дотриманням положень Конституції України і законів, що ухвалюються на ї̈ основі (Konstytutsiia Ukrainy). Ефективне функціонування правової держави $є$ можливим лише за 
умови, що вона сама єзаконом, фіксованою нормою, яка встановлюється верховною владою та здійснює контроль за іï дотриманням фізичними i юридичними особами.

3 огляду на це однією з головних ознак правової держави є здійснення державної влади відповідно до конституційно визначених владних повноважень між законодавчими, виконавчими i судовими органами. При цьому важливого значення набуває самостійність (передусім функціональна) виконавчої, законодавчої та судової гілок, а також реальна можливість здійснення взаємного контролю - це так званий механізм стримування і противаг - методи і форми правового обмеження дій однієї влади з боку іншої.

Отже, одним із найважливіших атрибутів правової держави, засобом забезпечення прав і свобод громадян $є$ поділ влади. Ш.-Л. Монтеск'є, який вважається засновником теорії поділу влад, зазначав, що досвід століть свідчить про те, що кожна людина, що наділена владою, схильна зловживати нею, і вона йде в цьому напрямку, поки не досягне покладеної їй межі. Щоб не було можливості зловживати владою, необхідний такий порядок речей, за якого різні влади могли б взаємно стримувати одна одну (Terekh, 1994, p. 40-44).

М. Марченко наголошує з приводу зазначеного, що на підставі однієї й тієї самої тези - про належність влади народові - у різних країнах і політичних ситуаціях надаються досить суперечливі висновки. Вчений констатує, що незважаючи на такі розбіжності думок стосовно цільності й ступеня оформленості, теорія існує, за визнанням більшості авторів, хоча й у незавершеному вигляді. Й існує вона передусім як одна з ознак правової держави (Marchenko, 2001, p. 305).

Починаючи від Дж. Локка і Ш.-Л. Монтеск'є, з іменами яких пов'язують активну розробку цієї теорії, і завершуючи сучасністю, вироблено конкретні, універсальні положення, які становлять основу цієї теорії.

Серед загальних, достатньо сталих, універсальних положень, які становлять основу теорії поділу влад, виокремлюються такі постулати: 1) у кожній країні, яка називає себе демократичною, законодавча, виконавча і судова влада не лише тісно пов'язані між собою єдиним державним механізмом, а й є відносно самостійними (Montesquieu, 1955, p. 308-314); 2) між вищими державними органами, що здійснюють законодавчі, виконавчі й судові функції, існує певний баланс влад, діє система стримувань і противаг; 3) усі три влади діють, як правило, на постійній правовій основі. Оскільки закони, як писав Дж. Локк, наділені постійною й непохитною силою і потребують безперервного виконання чи нагляду за їх виконанням, то необхідно, щоб увесь час існувала влада, яка спостерігала б за їх виконанням 
(Locke, 1988, p. 347); 4) верховенство законодавчої влади, яка зберігається завжди, незважаючи на відносну самостійність інших гілок влади та визначені межі її діяльності.

I, як наголошує М. Марченко, основною й остаточною метою здійснення на практиці теорії розподілу влад $€$ попередження узурпації усіх гілок державної влади однією особою чи групою осіб і збереження цілісності державного механізму й усього суспільства (Marchenko, 2004, p. 305-306).

М. Оніщук переконаний, що вдосконалення системи стримувань, противаг і балансів набуває в доктрині конституційної перебудови особливого значення як об'єктивна потреба з огляду на політичну незавершеність і недостатню зрілість української демократії, відсутність прямих кореляцій між інтересами громадян, нації, держави та корпоративними цінностями і завданнями політичних партій, слабкий вплив громадянського суспільства на владні інституції (Onischuk, 2009, р. 106).

Основними доктринальними чинниками, які визначають зміст удосконалення системи стримувань і противаг, є: закріплення неоднакових форм і способів формування окремих гілок влади; встановлення різних термінів їх повноважень; визначення чітких дискретних повноважень кожної з них; послідовне втілення у життя демократичних принципів організації та діяльності органів державної влади та їх посадових осіб; встановлення конституційно-правової відповідальності за допущені порушення дискретності; здійснення належного конституційного контролю за діяльністю суб'єктів владних повноважень з метою забезпечення верховенства права у їх взаємовідносинах (Skakun, 2009, р. 150).

Як зазначає О.Скрипнюк, структурно-організаційному визначенню принципу поділу влади відповідають такі ознаки, як самостійність державних інститутів, порядок розмежування їх функцій, діяльності та повноважень, а також визначення основних способів, каналів і механізмів їх взаємодії (Skrypniuk, 2000, p. 106).

Базовою ознакою функціонування правової держави й утвердження верховенства права О. Скакун називає сформованість громадянського суспільства, яке науковець формулює як суспільство із високорозвиненою системою взаємодії вільних і рівноправних громадян та їх об’єднань, де реально забезпечується дія принципу рівних можливостей вільно і безпечно розпоряджається своїми силами, здібностями, майном, керуючись правом і власною правосвідомістю. Виникнення та еволюція верховенства права і правової держави зумовлені саме потребами громадянського суспільства (Laba, 2009, p. 191).

За умов демократичного конституційного ладу держава і громадянське суспільство виступають як рівноцінні партнери, які шляхом взаємодії та 
пошуку компромісів забезпечують вирішення суспільних проблем (Subbotin, 2005, p. 168).

Отже, для правової держави характерне верховенство закону в усіх сферах суспільного життя. У правовій державі жоден державний орган, посадова особа, колективна або громадська організація, жодна людина не можуть посягати на закон. За його порушення вони несуть юридичну відповідальність [35, с. 120], під якою в юридичній літературі розуміють одну із форм або різновидів загальної соціальної відповідальності (Pigolkina, 1998, p. 332).

Як наголошує Н. Оніщенко, реальність свідчить про те, що людина виявляється менш захищеною перед державою і механізм її відповідальності є досить ефективним, на відміну від механізму відповідальності держави перед особою, який в Україні практично не діє. А саме останнє у контексті розвитку правової держави $є$ свідченням певного рівня демократичних перетворень. Тому особливу увагу в контексті становлення правової держави потрібно приділяти інституту відповідальності держави перед особою, як одній з основних гарантій прав i свобод людини, закріплених у чинному законодавстві. Завдяки цьому досягається послаблення тиску держави на суспільство і водночас підвищується можливість його контролю за діями держави, за рішеннями ії органів та посадових осіб (Onischenko, 2009, p. 53).

Об’єктивний аналіз реальної дійсності свідчить, що Україна перебуває на шляху становлення правової держави, що супроводжується низкою проблем. Зокрема, відсутністю ефективного контролю за діяльністю органів влади з боку громадськості, що зумовлено нерозвиненістю інститутів громадянського суспільство, яке, власне, і повинно здійснювати цю функцію.

Окрім того, примусовий характер політичної влади, негативний відтінок у сприйнятті її суспільством породжує проблему легітимності влади як переконання підвладних і міжнародної спільноти у її правомірності, як визнання існуючої влади. Як слушно зазначає О. Шестопал, легітимність - це факт свідомості людей (Shestopal, 2002, р 64).

\section{Висновки}

Отже, відбулися суттєві зрушення в оцінці прав і свобод людини, y їх конституційно-правовому регулюванні, окреслено шляхи їх реалізації та створені відповідні правові механізми. Україна визнала юрисдикцію європейських інститутів захисту прав і свобод людини. Піддається глибокій трансформації національна система законодавства. Оновлюється значна кількість правових інститутів, які забезпечують реалізацію прав і свобод громадян. Забезпечується ідеологічна і політична свобода, вільна діяльність політичних партій. 


\section{References:}

1. Dzoban, O.P. (2005). 'Do pytannia pro osmyslennia sutnosti pravovoi derzhavy' [On the question of understanding the essence of the rule of law]. Biuleten Ministerstva yustytsii Ukrainy [Bulletin of the Ministry of Justice of Ukraine], no. 9, pp. 23-30.

2. Goncharov, P. K. (2000). 'Sotsial'noe gosudarstvo: sushchnost' i printsipy' [The social state: essence and principles]. Vestnik Rossiiskogo universitet adruzhby narodov [Bulletin of Peoples' Friendship University of Russia], no. 2, pp. 46-59.

3. Jaspers ,K. (1994). Smysl i naznachenie istorii [Meaning and purpose of history]. Moscow: Respublika.

4. Konstytutsiia Ukrainy : stanom na (07 liutoho 2019 roku). [Constitution of Ukraine (2019, February 02)]. Verkhovana Rada Ukrainy, [online]. Availiable at: https://zakon.rada.gov.ua/laws/show/254\%D0\%BA/96-\%D0\%B2\%D1\%80 [Accessed 20 March 2019].

5. Koziubra, M. I. (2003). 'Pravovyi zakon: problema kryteriiv' [Legal Law: The Problem of Criteria]. Visnyk Akademii pravovykh nauk Ukrainy [Bulletin Academy of legal sciences of Ukraine],no. 2 (33), pp. 83-96.

6. Kresina, I. O., ed. (2006). Polityka, pravo $i$ vlada $v$ konteksti transformatsiinykh protsesiv $v$ Ukraini [Politics, the right and the vlada in the context of transformation processes in Ukraine]. Kyiv: Institute of State and Law named after V.M. Koretsky, National Academy of Sciences of Ukraine.

7. Kultenko, V. I. (2004). Istoryko-filosofska rekonstruktsiia kontseptsii pryrodnoho prava $v$ konteksti analizu perekhidnykh suspilstv [Historical and philosophical reconstruction of the concept of natural law in the context of the analysis of transition societies]. D.Ed. Kyiv, National Agrarian University.

8. Laba, O. V. (2009). 'Pryntsypy pravovoi derzhavy ta problemy yii pobudovy $\mathrm{v}$ Ukraini' [Principles of the rule of law and the problems of its construction in Ukraine]. Pravova derzhava [Constitutional state], no. 20, pp. 163-170.

9. Locke, J. (1988). Sochineniya [Writings], Vol. 3. Moscow: Mysl'.

10. Marchenko, M. N (2001). Problemy teorii gosudarstva i prava [Issues of the theory of state and law]. Moscow: Progres.

11. Marchenko, M. N., ed. (1993). Politologiya [Political science]. Moscow: Moscow State University Publishing House.

12. Marchenko, N. M. (2007). Obshchaya teoriya gosudarstva i prava [General Theory of State and Law]. Moscow: Norma.

13. Montesquieu, Ch. (1955). Izbrannye proizvedeniya [Selected Works]. Moscow: Gospolitizdat.

14. Onischenko, N M. (2009). 'Zakhyst prav i svobod liudyny v Ukraini' [Protection of human rights and freedoms in Ukraine]. Pravo Ukrainy [Law of Ukraine], no. 4, pp. 47-54. 
15. Onischuk, M. V., ed. (2009). Referendna demokratiia: problemy konstytutsiinoi teorii ta praktyky [Referential Democracy: Issues of Constitutional Theory and Practice]. Kyiv: European University Publishing House.

16. Onishchenko, N. M., ed. (2007). Problemy realizatsii prav i svobod liudyny ta hromadianyna $v$ Ukraini [Problems of realization of human and citizen rights and freedoms in Ukraine]. Kyiv: Yurydychna dumka, pp. 90-123.

17. Osetynskyi, V. (2019). Vvedennia u kontseptsiiu prav liudyny. [Introduction to the concept of human rights], [online]. Available at: http://www.ccf.org.ua/forsocial-workers-article [Accessed 20 March 2019].

18. Pigolkina,A. S., ed. (1998). Obshchaya teoriya prava [General theory of law. Moscow: Bauman Moscow State Technical University Publishing House.

19. Plavych, V. P. (2012). 'Pravo na suchasnomu etapi rozvytku yurydychnoi nauky' [Right at the present stage of the development of legal science]. Visnyk Odeskoho natsionalnoho universytetu [Bulletin of Odessa National University], Vol. 17, issue 7, pp. 7-19.

20. Popov, B. (1995). 'Natsionalne buttia $\mathrm{v}$ sferi polityky, ideolohii, dukhovnosti' [National Being in the Sphere of Politics, Ideology, Spirituality]. Filosofska i sotsiolohichna dumka [Philosophical and Sociological Thought], no. 11-12, pp. 237-240.

21. Rabinovych, P. M. (1996). Sotsialna derzhava. Mala entsyklopediia derzhavotvorennia [Social state. Small Encyclopedia of State Creation]. Kyiv: Henesa dovira.

22. Saveliev, V. (1997). Hromadianske suspilstvo i pravova derzhava: problemy stanovlennia [Civil society and the rule of law: the problems of becoming]. Kyiv: Naukova dumka.

23. Selivanov, A. O. (2012). 'Vid pravovoi do konstytutsiinoi derzhavy: shliakh teorii i praktyky evoliutsiinykh zmin' [From legal to constitutional state: the path of theory and practice of evolutionary change]. Almanakh prava. Osnovopolozhni pryntsypy prava yak yoho tsinnisni vymiry [Almanac of law. The fundamental principles of law as its value measurements], issue 3, pp. 19-21.

24. Shapova, V. (2004). 'Konstytutsina katehoriia sotsialnoi derzhavy' [Constitutional category of social state]. Pravo Ukrainy [Law of Ukraine], no. 5, pp. 14-19.

25. Shemshuchenko, Yu. (2013). 'Do pytannia pro formuvannia i rozvytok derzhavno-pravovykh instytutiv nezalezhnoi Ukrainy' [To the question of formation and development of state-legal institutes of independent Ukraine]. Biuleten Ministerstva yustytsii Ukrainy [Bulletin of the Ministry of Justice of Ukraine], no. 8, pp. 5-12. 
26. Shemshuchenko, Yu. ed. (2012). Zavdannia ta funktsii suchasnoho etapu rozvytku pravovoi systemy [Tasks and functions of the modern stage of development of the legal system, Kyiv: Yurydychna dumka.

27. Shestopal, E. B., ed. (2002). Politicheskaya psikhologiya [Political psychology]. Moscow: Infra-M.

28. Shliakhtun, P. P. (2002). Politolohiia [Politology]. Kyiv: Lybid.

29. Skakun, O. F., ed. (2009). Theory of Law and Powers. Kiev: CST; TSUL.

30. Skrypniuk, O. V., ed. (2000). Sotsialna, pravova derzhava v Ukraini: problemy teorii i praktyky [Social, legal state in Ukraine: problems of theory and practice]. Kyiv: Institute of State and Law named after V. M. Koretsky, National Academy of Sciences of Ukraine.

31. Solovykh, V. P. (2009). 'Kontseptsiia «sotsialnoi derzhavy» ta yii vplyv na derzhavne upravlinnia' [The concept of a "social state" and its influence on state governance]. Aktualni problemy derzhavnoho upravlinnia [Actual problems of public administration], no. 2 (36), pp. 71-77.

32. Subbotin, V. M, ed. (2005). Teoriia derzhavy i prava [Theory of state and law]. Kyiv: Znannia.

33. Terekh, O. I. (1994). Nevycherpnist demokratii : Vydatni diiachi mynuloho $i$ suchasnosti pro vilne, demokratychne suspilstvo i prava liudyny [The inexhaustibility of democracy: Outstanding figures of the past and the present about a free, democratic society and human rights]. Kyiv: Ukrainskyi pysmennyk.

34. Tolstenko, V. (2014) 'Instytuty bezposerednoho narodovladdia u vyznachenni formy suchasnoi derzhavy' [Institutes of direct democracy in determining the shape of a modern state]. Pravo Ukrainy [The Law of Ukraine], no. 2, pp. 171-179.

35. Yuzvikov, V.A. (2004). Priroda pravovoi gosudarstvennosti: sotsial'nofilosofskii analiz [The nature of legal statehood: a socio-philosophical analysis]. D.Ed. Moscow State University.

36. Zaichuk, O. V. (2012). 'Pryntsypy prava v konteksti rozvytku zahalnoi teorii derzhavy i prava' [rinciples of law in the context of the development of the general theory of state and law]. Almanakh prava. Osnovopolozhni pryntsypy prava yak yoho tsinnisni vymiry [Almanac of law. The fundamental principles of law as its value measurements], issue 3, pp. 22-26.

37. Zakon Ukrainy Pro Natsionalne antykoruptsiine biuro Ukrainy : stanom na (03 Lypnia 2018 roku) [Law of Ukraine On the National Anti-corruption Bureau of Ukraine (2018, July 03)]. Verkhovana Rada Ukrainy, [online]. Availiable at: https://zakon.rada.gov.ua/laws/show/1698-18 [Accessed 20 March 2019].

(C) Биркович Т. І., Кабанець О. С., 2019 